\title{
Isolation and Partial Characterization of the Human aA-Crystallin Gene
}

There are several reasons for stressing the importance of isolating $\alpha$-crystallin genes from different species. From an evolutionary viewpoint, $\alpha$-crystallin is highly conserved (see de Jong, 1981, 1982), making small changes in primary structure very interesting. Moreover, the unexpected relationship between $\alpha$-crystallin and Drosophila heat-shock proteins (Ingolia and Craig, 1982) is intriguing and requires detailed examination (see Wistow, 1985). From a developmental viewpoint, $\alpha$-crystallin is the first crystallin to appear in some, but not all, species (see Piatigorsky, 1981). It is also interesting that the two $\alpha$-crystallin genes $(\alpha A$ and $\alpha B$ ) are differentially expressed during lens cell differentiation (Delcour and Papaconstantinou, 1974; Vermorken and Bloemendal, 1978). Another possible benefit from comparative studies of $\alpha$-crystallin genes is to gain a better understanding of the molecular and biological basis for the selective appearance of the $\alpha A^{\text {ins }}$ polypeptide in certain rodents (Cohen, Westerhuis, de Jong and Bloemendal, 1978); the $\alpha A^{\text {ins }} \mathrm{mRNA}$ is a product of alternative RNA splicing of the $\alpha A$-crystallin gene (King and Piatigorsky, 1983). Finally, the numerous post-translational modifications associated with $\alpha$-crystallin (e.g. aggregation, cleavage and racemization) during lens aging and cataract give special importance to the isolation of human $\alpha$-crystallin genes (see Spector, 1973; Zigler and Goosey, 1981; Hoenders and Bloemendal, 1983; Harding and Crabbe, 1984).

At present, genomic clones of the $\alpha A$-crystallin gene have been isolated from the mouse (King and Piatigorsky, 1983), hamster (van den Heuval, Hendricks, Quax and Bloemendal, 1985) and chicken (Yasuda, Okazaki, Kondoh, Shimura and Okada, 1983; Thompson, Hawkins and Piatigorsky, in preparation), while a genomic clone of the $\alpha$ B-crystallin gene has been obtained only from the hamster (Quax-Jeuken, Quax, van Rens, Khan and Bloemendal, 1985). Here we have used a murine $\alpha A$-crystallin cDNA probe to isolate the human $\alpha$ A-crystallin gene.

Two human genomic libraries (partial Mbo I digests of placenta and spleen DNA, respectively, cloned without linkers into hacteriophage $\lambda$ Charon 28 ; gift of $\mathrm{Dr}$ Philip Leder) were screened with $\mathrm{pM} \alpha \mathrm{ACr} 2$, a murine $\alpha \mathrm{A}_{2}$-crystallin cDNA (King, Shinohara and Piatigorsky, 1982). The cDNA insert was isolated electrophoretically from $\mathrm{pM} \alpha \mathrm{ACr} 2$ after digestion with Pst I and nick-translated (Maniatis, Jeffrey and Kleid, 1975) before use for hybridization. Each library was screened (total $10^{6}$ bacteriophage plaques per library) by the colony hybridization method of Benton and Davis (1977) using $1.5 \times 10^{6}$ counts per filter. Hybridization $(12 \mathrm{hr})$ was performed at $68{ }^{\circ} \mathrm{C}$ in $2 \times \mathrm{SSC}$ (standard saline citrate) and Denhardt's solution (1966). The washes for the first screening were at $63^{\circ} \mathrm{C}$ with $2 \times \mathrm{SSC}$, while those for the second and third screenings were at $68{ }^{\circ} \mathrm{C}$ with $2 \times \mathrm{SSC}$; all washes contained $0.5 \%$ SDS. Ten positive clones were obtained after the three screenings (six from the spleen DNA and four from the placenta DNA). Considering that the DNA library contains overlapping inserts, this number is consistent with the presence of very few, if not a single, $\alpha$ A-crystallin gene.

Restriction analysis of the 10 genomic clones indicated that there were five recombinant bacteriophage containing different inserts (data not shown). These 


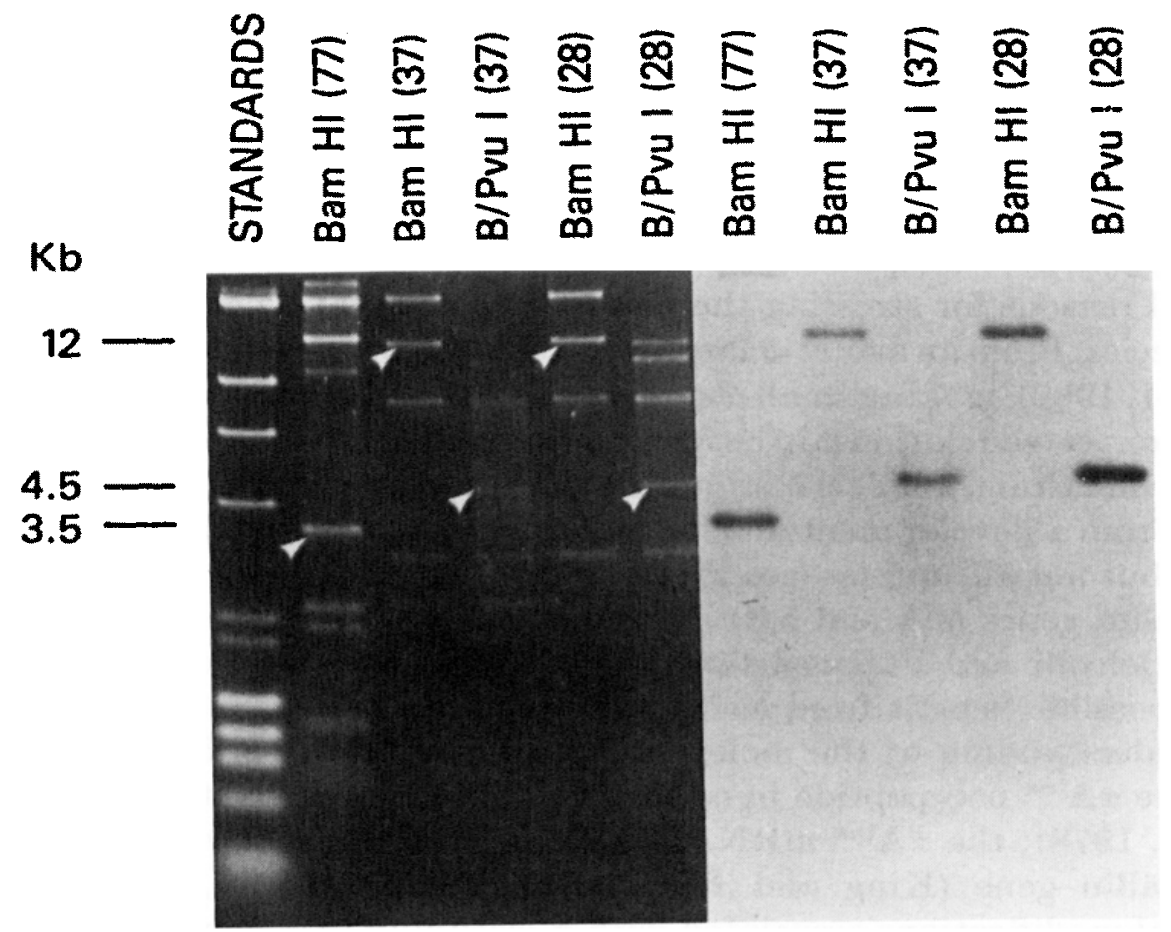

Fia. 1. Left panel. Agarose gel electrophoresis of DNA from three recombinant bacteriophage clones: $\mathrm{g} \lambda \mathrm{H} \alpha \mathrm{Cr} 77$ (77), $\mathrm{g} \lambda \mathrm{H} \alpha \mathrm{Cr} 37$ (37) and $\mathrm{g} \lambda \mathrm{H} \alpha \mathrm{Cr} 28$ (28). Bam HI and Bam HI (B)/Pvu I double digestions, as noted. DNA size standards include $\lambda$ DNA digested with Hind III and $\Phi$ X-174 DNA digested with Hae 1II. White arrowheads indicate fragments hylridizing with the $\alpha A$-erystallin aDNA probe. Electrophoresis was in $0.9 \%$ agarose in $40 \mathrm{~mm}$ Tris-HCl, pH 8.2, $2 \mathrm{~mm}$ EDTA, $20 \mathrm{~mm}$ Na acetate and $18 \mathrm{~mm} \mathrm{NaCl}$; the gel was stuined with ethidium bromide. Right panel. Southern blot hybridization of the same gel with the ${ }^{32} \mathrm{P}$-nick-translated murine $\alpha A$-crystallin cDNA probe.

clones were examined further ( $\mathrm{g} \lambda \mathrm{H} \alpha \mathrm{Cr} 37$ from the placenta DNA library, and g $\lambda \mathrm{H} \alpha \mathrm{Cr} 28$ and $\mathrm{g} \lambda \mathrm{H} \alpha \mathrm{Cr} 77$ from the spleen DNA library). Southern blot analysis (Southern, 1975) showed that the sequences which hybridized to the $\alpha$ A-crystallin cDNA are situated on a $3.5 \mathrm{~kb}$ Bam HI fragment of $\mathrm{g} \lambda \mathrm{H} \alpha \mathrm{Cr} 77$ and on a $4.5 \mathrm{~Kb} \mathrm{Bam}$ $\mathrm{HI} / \mathrm{Pvu} \mathrm{I}$ fragment of $\mathrm{g} \lambda \mathrm{H} \alpha \mathrm{Cr37}$ and $\mathrm{g} \lambda \mathrm{H} \alpha \mathrm{Cr} 28$ (Fig. 1). Digestion of $\mathrm{g} \lambda \mathrm{H} \alpha \mathrm{Cr} 37$ and g $\lambda \mathrm{H} \alpha \mathrm{Cr} 28$ with Bam $\mathrm{HI}$ alone gave a $12 \mathrm{~Kb}$ band which hybridized to the nicktranslated cDNA (Fig. 1). The relatively large size of this fragment was due to the fact that only one of the end Mbo I sites of the genomic insert was converted to a Bam HI site during the cloning procedure. Thus, only approximately $3 \cdot 3 \mathrm{~Kb}$ of each $12 \mathrm{~Kb}$ fragment are genomic in origin, the remainder being derived from the bacteriophage arm. Further restriction analysis revealed that $\mathrm{g} \lambda \mathrm{H} \alpha \mathrm{Cr} 28$ and $\mathrm{g} \lambda \mathrm{H} \alpha \mathrm{Cr} 37$ have at least $11 \mathrm{~Kb} 5^{\prime}$ to the $3.3 \mathrm{~Kb} \mathrm{Bam} \mathrm{HI} / \mathrm{Pvu} \mathrm{I}$ fragment containing the $\alpha \mathrm{A}$-crystallin sequences, while $\mathrm{g} \lambda \mathrm{H} \alpha \mathrm{Cr} 77 \mathrm{has}$ about $12 \mathrm{~Kb} 3^{\prime}$ to the $3.5 \mathrm{~Kb} \mathrm{Bam}$ HI fragment containing the $\alpha A$-crystallin sequences (data not shown).

We next identified the $\alpha A$-crystallin gene within $\mathrm{g} \lambda \mathrm{H} \alpha \mathrm{Cr} 77$ phage by sequencing. This phage was digested with Alu I and the resulting fragments were cloned into a Sma I-cut M13 mp8 vector (Messing and Vieira, 1982). Positive subclones were identified by hybridization with $\mathrm{pM} \alpha \mathrm{ACr} 2$ and sequenced by the dideoxy-chain termination method (Sanger, Nicklen and Coulson, 1977), as described by Biggen, Gibson and Hong (1983). The results established that the $3.5 \mathrm{~Kb} \mathrm{Bam} \mathrm{HI}$ fragment in $\mathrm{g} \lambda \mathrm{H} \propto \mathrm{Cr} 77$ contains the human $\propto \mathrm{A}$-crystallin gene. The 189 nucleotides given on 


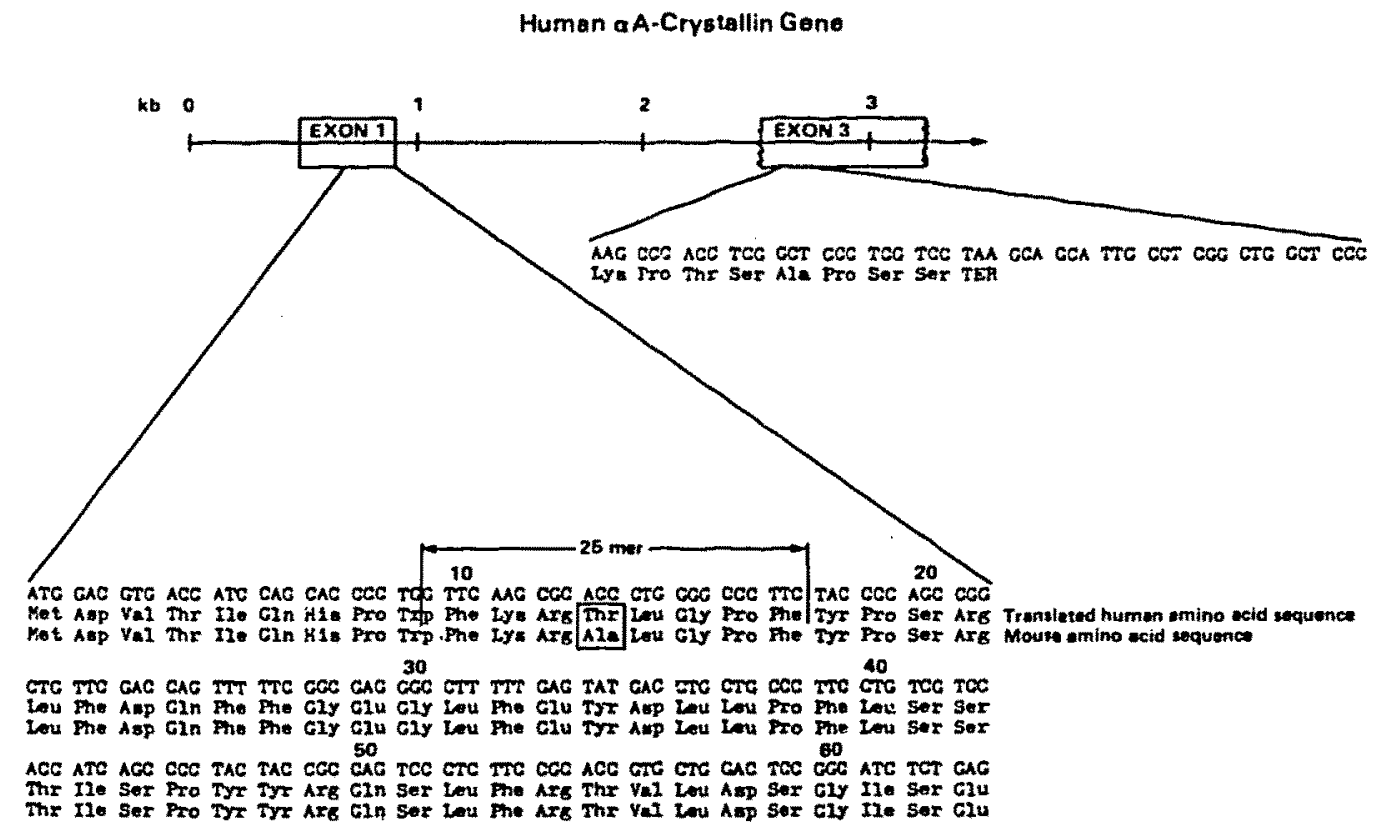

Fra. 2. Deduced partial structure of the human $\alpha \mathrm{A}$-crystallin gene in $\mathrm{g} \lambda \mathrm{H} \alpha \mathrm{Cr} 77$. The protein coding sequence in exon 1 and for the C-terminal end of the $\alpha A$-crystallin polypeptide are shown. These sequences were derived from a single strand of DNA. The nucleotide sequence for the C-terminus of the protein is assumed to be in exon 3 by analogy with the $\alpha A$-crystallin gene from other species (see text). The thr-ala difference between the mouse and human $a$-crystallin polypeptide at position 13 is boxed. The 25-mer oligonucleotide used in Fig. 4 is indicated. The numbers above the sequence refer to amino-acid residue number in the protein. See text for further discussion.

the left side of Fig. 2 encode the first 63 amino acids of the human $\alpha A$-crystallin polypeptide (de Jong, Terwindt and Bloemendal, 1975). By analogy with the known structure of the $\alpha$ A-crystallin gene of the mouse (Kir.g and Piatigorsky, 1983) and hamster (van den Heuval et al., 1985), we assume that this human coding sequence is located on exon 1. Experiments to be presented elsewhere support this assumption.

Interestingly, the $3^{\prime}$ splice site for exon 1 in the murine and human $\alpha \mathbf{A}$-crystallin gene occurs after the codon for amino acid 63 (glu) (Fig. 2). There is evidence that this exon has resulted from duplication and fusion of an ancestral sequence (Barker, Ketchan and Dayhoff, 1978; Wistow, 1985; van den Heuval et al., 1985). As noted earlier by protein sequencing (de Jong, 1982; de Jong and Goodman, 1982), there is only a single amino acid difference (thr in the human and ala in the mouse at position 13) of the encoded $\alpha$ A-crystallin protein in exon 1 (boxed in Fig. 2). Position 13 is occupied by thr also in the tapir, rhinoceros, ox and rabbit, by pro in the lemur, galago and potto, and by ser in the dogfish, indicating that this position is not invariant (de Jong, 1982).

Figure 3 compares the nucleotide sequence of the coding region of exion 1 of the human and murine $\alpha \mathrm{A}$-crystallin gene. There are only 12 nucleotide differences between these sequences (6.3\% change) despite the 70-80 million years of divergence between mouse and man (de Jong, 1982). All but one of these occur at the third position of the codons and do not result in an amino acid change. The ala $\rightarrow$ thr change noted above is due to a $G \rightarrow A$ change at position one of codon 13 (boxed in Fig. 3 ).

The $3^{\prime}$ end of the coding region of the $\alpha A$-crystallin gene was found in another Alu I fragment derived from $\mathrm{g} \lambda \mathrm{H} \alpha \mathrm{Cr} 77$ (Fig. 2, right side). Again, by analogy with the 


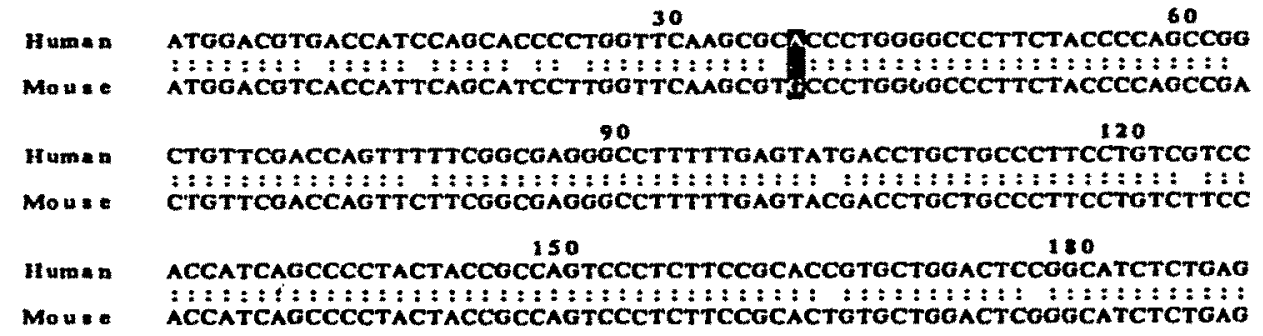

Fio. 3. Comparison of the coding regions in exon 1 of the human and mouse. The only non-third position difference is boxed and occurs in codon 13. See text. Numbers above sequence refer to nucleotide position.

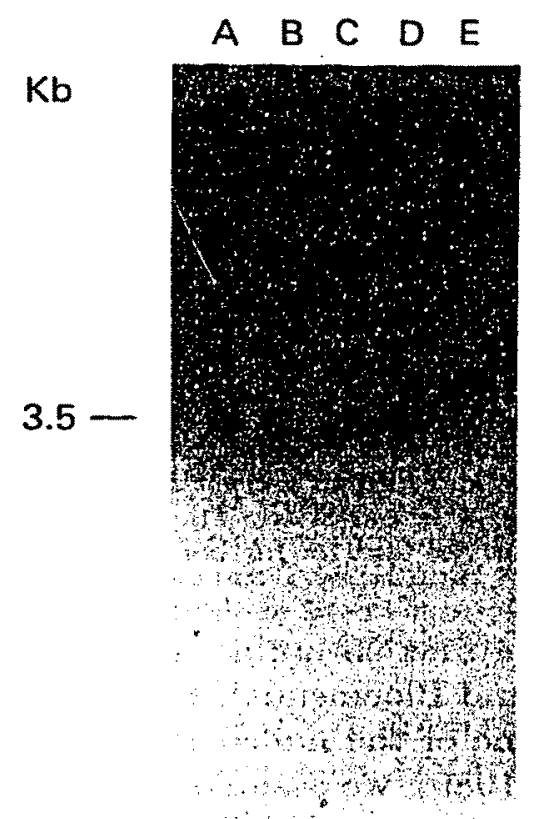

Fia. 4. Southern blot hybridization of Bam HI-digested genomic DNA from five different individuals. The 25 -mer oligonucleotide probe indicated in Fig. 2 was synthesized by OCS Labs, Denton, Texas. It was labeled to a specific activity of about $10^{6} \mathrm{cpm} \mu \mathrm{g}^{-1}$ DNA by hybridization with a 15-mer complement followed by extension with Klenow fragment of DNA polymernse using four $\alpha_{-}^{-32} \mathbf{P}-\mathrm{dNTP8}$. Hybridization procedures are given by Miyada, Klofelt, Reyes, McLaughlin-Taylor and Wallace (1985). This probe was hybridized with a dried denatured, neutralized and rehydrated $0.9 \%$ agarose gel using $2.0 \times\left. 10^{\circ} \mathrm{cpm} \mathrm{m}\right|^{-1}$. Hybridization was carried out at $68^{\circ} \mathrm{C}$ for $3 \mathrm{hr}$ followed by two $15-\mathrm{min}$ washes at $25^{\circ} \mathrm{C}$, one 2-hr wash at $25^{\circ} \mathrm{C}$ and one $90-\mathrm{sec}$ wash at $68^{\circ} \mathrm{C}$. All washes were in $6 \times \mathrm{SSC}(0.9 \mathrm{M} \mathrm{NaCl}$, $90 \mathrm{~mm}$ sodium citrate, pH 7.2). Autoradiography was with Kodak XAR-5 film for 15 hr at $-70^{\circ} \mathrm{C}$ with an intensifying screen.

known structure of the hamster $\alpha A$-crystallin gene (van den Heuval et-al., 1985) we assume that the sequences encoding the C-terminus of the protein are located on exon 3. The numbering of these exons depends on the assumption that the insert exon present in the mouse (King and Piatigorsky, 1983) and hamster (called exon 2 in this species, van den Heuval et al., 1985) is absent in the human.

Finally, we performed a Southern blot on Bam HI-digested DNA from tissue samples of five individuals in order to provide further evidence that there is only a single $\alpha$ A-crystallin gene in humans. Hybridization was performed with a radioactively labeled 25-mer oligonucleotide probe encoding amino acids 10 to 17 of the $\alpha A$-crystallin 
polypeptide (indicated in Fig. 2) on the dried agarose gel. The 25-mer probe has minimum and maximum mismatches with the human $\alpha \mathrm{B}$-crystallin gene of $32 \%$ and $64 \%$, respectively, as calculated from the known sequence of the human $\alpha B$ protein (Kramps, de Man and de Jong, 1977) and the ambiguity of the genetic code. The oligomeric probe hybridized exclusively to a $3.5 \mathrm{~Kb}$ Bam HI DNA fragment from each individual (Fig. 4). In another test, this $3.5 \mathrm{~Kb}$ Bam $\mathrm{HI}$ fragment co-migrated with the $3.5 \mathrm{~Kb}$ insert in $\mathrm{g} \lambda \mathrm{H} \alpha \mathrm{Cr} 77$ which contains the $\alpha \mathrm{A}$-crystallin gene. This result is consistent with the interpretation that there is a single $\alpha \mathrm{A}$-crystallin gene in the human and that this gene is present in $\mathrm{g} \lambda \mathrm{H} \alpha \mathrm{Cr} 77$. Additional experiments using pM $\alpha A C r 2$ (the cDNA probe) revealed the presence of this hybridizing $3.5 \mathrm{~Kb}$ Bam $\mathrm{HI}$ DNA fragment in 16 individuals. Thus, it appears as if the human $\alpha A$-crystallin gene is not highly polymorphic.

In summary, we have isolated the $\alpha$ A-crystallin gene in humans by using a nearly full-length cDNA probe from mice. There appears to be only one $\alpha A$-crystallin gene in man as in mouse (King and Piatigorsky, 1983), hamster (van den Heuval et al., 1985) and chicken (Thompson et al., in preparation). A recent investigation using somatic cell hybrids indicates that this gene is located on human chromosome 21 (Quax-Jeuken et al., 1985). Our data indicate that the size and structure of the human $\alpha$ A-crystallin gene are generally similar to that in the other organisms examined. The first intron of the human gene is situated after codon 63 as it is in the mouse (King and Piatigorsky, 1983), hamster (van den Heuval et al., 1985) and chicken (Yasuda et al., 1983; Thompson et al., in preparation). We presume that the human $\alpha$ A-crystallin gene lacks an insert exon (King and Piatigorsky, 1983) and that codons 64-104 are contained on a separate exon as in the other organisms, but this remains to be established. The present isolation of the human $\alpha$ A-crystallin gene extends our ability to conduct comparative studies on this highly conserved lens protein, which should deepen our understanding of its selective expression (Chepelinsky, King, Zelenka and Piatigorsky, 1985; Okazaki, Yasuda, Kondoh and Okada, 1985; Overbeek, Chepelinsky, Khillan, Piatigorsky and Westphal, 1985) and alternative RNA splicing (King and Piatigorsky, 1983). The availability of the human $\alpha A$-crystallin gene should also facilitate studies concerning the possible involvement of $\alpha \mathrm{A}$-crystallin in cataract.

Laboratory of Molecular and Developmental Biology,

National Eye Instilute

and National Institutes of Health, Bethesda, MD 20892.
David S. MCDevitT* JAMES W. HAWkins

Cynthia J. Jaworski and Joram Piatigorsky

(Received 22 January 1986 and accepted 14 February 1986)

\section{ACKNOWLEDGMENT}

We thank Mrs Dawn Chicchirichi for expert typing. A part of this research was supported by an NIH grant (EY-02534) to D. S. McDevitt. We also want to thank Drs Graeme Wistow and Albine Katial for technical advice and Dr T. J. Ley for assistance.

* Present address: Department of Animal Biology, University of Pennsylvania, School of Veterinary Medicine, Philadelphia, PA 19104. 


\section{REFERENCES}

Barker, W. C., Ketchan, L. K. and Dayhoff, M. O. (1978). A comprehensive examination of protein sequences for evidence of internal gene duplication. J. Mol. Evol. 10, 205-81.

Benton, W. D. and Davis, R. W. (1977). Screening $\lambda$ gt recombinant elones by hybridization to single plaques in situ. Science 196, 180-2.

Biggen, M. D., Gibson, T. J. and Hong, G. F. (1983). Buffer gradient gels and ${ }^{36} \mathrm{~S}$ label as an aid to rapid DNA sequence determination. Proc. Nal. Acad. Sci. U.S.A. 80, 3963-5.

Chepelinsky, A. B., King, C. R., Zelenka, P. S. and Piatigorsky, J. (1985). Lens-8pecific expression of the chloramphenicol acetyltransferase gene promoted by 5 ' flanking sequences of the murine $\alpha A$-crystallin gene in explanted chicken lens epithelia. Proc. Nat. Acad. Sci. U.S.A. 82, 2334-8.

Cohen, L. H., Westerhuis, L. W., Smits, D. P. and Bloemendal, H. (1978). Rat $\alpha$-crystallin A chain with an insertion of 22 residues. Eur. $J$. Biochem. 89, 259-66.

Delcour, J. and Papaconstantinou, J. (1974). A change in the stoichiometry of assembly of bovine lens $\alpha$-crystallin subunits in relation to cellular differentiation. Biochem. Biophys. Res. Comm. 57, 134-41.

Denhardt, D. T. (1966). A membrane-filter technique for the detection of complementary DNA. Biochem. Biophys. Res. Comm. 23, 641-6.

Harding, J. J. and Crabbe, M. J. C. (1984). The lens: development, proteins, metabolism and cataract. In The Eye (3rd ed.) (Ed. Davson, H.). Pp. 207-492. Academic Press: New York.

van den Heuval, R., Hendricks, W., Quax, W. and Bloemendal, H. (1985). Complete structure of the hamster $\alpha \mathrm{A}$-crystallin gene. Reflection of an evolutionary history by means of exon suffling. J. Mol. Biol. 185, 273-84.

Hoenders, H. J. and Bloemendal, H. (1983). Lens proteins and aging. J. Gerontol. 38, 278-86.

Ingolia, T. D. and Craig, E. A. (1982). Four small Drosophila heat shock proteins are related to each other and to mammalian $\alpha$-crystallin. Proc. Nat. Acad. Sci. U.S.A. 79, 2360-4.

de Jong, W. W. (1981). Evolution of lens and crystallins. In Molecular and Cellular Biology of the Eye Lens (Ed. Bloemendal, H.). Pp. 221-78. John Wiley and Sons: New York.

de Jong, W.W. (1982). Eye lens proteins and vertebrate evolution. In Macromolecular Sequences in Systematic and Evolutionary Biology (Ed. Goodman, M.). Pp. 75-114. Plenum Publishing Corp.

de Jong, W. W. and Goodman, M. (1982). Mammalian phylogeny studied by sequence analysis of the eye lens protein $\alpha$-crystallin. Sonderd. $Z$. Saugetierkunde 47, 257-76.

de Jong, W. W., Terwindt, C. and Bloemendal, H. (1975). The amino acid sequence of the A chain of human $\alpha$-crystallin. FEBSS Lett. 58, 310-13.

King, C. R., Shinohara, T. and Piatigorsky, J. (1982). $\alpha$ A-Crystallin messenger RNA of the mouse lens: more non-coding than coding sequences. Science 215, 985-7.

King, C. R. and Piatigorsky, J. (1983). Alternative RNA splicing of the murine $\alpha$ A-crystallin gene: protein coding information within an intron. Cell 32, 707-12.

Kramps, J. A., de Man, B. M. and de Jong, W. W. (1977). The primary structure of the B2-chain of human $\alpha$-crystallin. FEBS Lett. 74, 82-4.

Maniatis, T., Jeffrey, A. and Kleid, D. G. (1975). Nucleotide sequence of the rightward operator of phage A. Proc. Nat. Acad. Sci. U.S.A. 72, 1184-8.

Messing, J. and Vieira, J. (1982). A new pair of M13 vectors for selecting either DNA strands or double digest restriction fragments. Gene 19, 269-76.

Miyada, C. G., Klofelt, C., Reyes, A. A., McLaughlin-Taylor, E. and Wallace, R. B. (1985). Evidence that polymorphism in the murine major histocompatibility complex may be generated by the assortment of subgene sequences. Proc. Nut. Acad. Sci. U.S.A. 82, $2890-4$.

Okazaki, K., Yasuda, K., Kondoh, H. and Okada, T. S. (1985). DNA sequences responsible for tissue-specific expression of a chicken $\alpha$-crystallin gene in mouse lens cells. $E M B O$ $J .4,2589-95$.

Overbeek, P. A., Chepelinksy, A. B., Khillan, J. S., Piatigorsky, J. and Westphal, H. (1985). Lens-specific expression and developmental regulation of the bacterial chloramphenicol 
acetyltransferase gene driven by the murine $\alpha \mathrm{A}$-crystallin promoter in transgenic mice. Proc. Nat. Acad. Sci. U.S.A. 82, 7815-19.

Piatigorsky, J. (1981). Iens differentiation in vertebrates. A review of cellular and molecular features. Differentialion 19, 134-53.

Quax-Jeuken, Y., Quax, W., van Kens, G., Khan, P. M. and Bloemendal, H. (1985). Complete structure of the $\alpha \mathrm{B}$-crystallin gene : conservation of the exon-intron distribution in the two nonlinked $\alpha$-crystallin genes. Proc. Nat. Acad. Sci. U.S.A. 82, 5819-23.

Sanger, F., Nicklen, S. and Coulson, A. R. (1977). DNA sequencing with chain-terminating inhibitors. Proc. Nat. Acad. Sci. U.S.A. 74, 5463-7.

Southern, E. M. (1975). Detection of specific sequences among DNA fragments separated by gel electrophoresis. J. Mol. Biol. 98, 503-17.

Spector, A. (1973). The aging of alpha-crystallin: a review. Exp. Eye Res. 16, 115-21.

Vermorken, A. J. M. and Bloemendal, H. (1978). $\alpha$-Crystallin polypeptides as markers of lens cell differentiation. Nature (London) 271, 779-81.

Wistow, G. (1985). Domain structure and evolution in $\alpha$-crystallin and small heat-shock proteins. FEBS Letl. 181, 1-6.

Yasuda, K., Okazaki, K., Kondoh, H., Shimura, Y. and Okada, T. S. (1983). The organization and structure of $\alpha$ - and $\delta$-crystallin genes in the chicken. 12th NIBB Conference on Molecular Mechanisms of Cell Specialization in Development, Dec. 14-16, National Institute for Basic Biology, Okazaki, Japan.

Zigler, J. S., Jr and Goosey, J. (1981). Aging of protein molecules: lens crystallins as a model system. Trends Biol. Sci. 6, 133-6. 